\title{
ПРАВОВІ ЗАСАДИ ДЕРЖАВНОӤ ПОЛІТИКИ У СФЕРІ КУЛЬТУРИ ТА МИСТЕЦТВА
}

\author{
СРМАКОВА Ганна Станіславівна - доктор юридичних наук професор \\ кафедри гуманітарних дисциплін Національної академії керівних кадрів культури \\ і мистецтв \\ УДК 35.075.1:342.2:321 \\ DOI 10.32782/NP.2021.3.19
}

Статтю присвячено дослідженню сутності та особливостей суспільних відносин у сбері культури та мистецтва і з'ясуванню тенденизй подальшого впливу держави на культурну сферу. Методологія дослідження сфери культури та мистеитва базується на положеннях загальнонаукового діалектичного методу. Разом 3 ицм, для більи детального та грунтовного розкриття теми наукової статті було використано формально-юридичний $i$ формальнологічний методи. Обгрунтовано, що відносини у сфбері культури та мистеитва мають господарсъку приватно-правову природу. Основні засади державної політики у иій сфері в Украйні врегулювано на законодавчому рівні, що слід, безперечно, вважати позитивним фактором для подальшої адаптащй законодавства Украӥни до законодавства ЕС. Доведено, що на съогодні основними приниипами, на яких грунтується державна політика у сфері культури та мистецтва, є приниип прозорості і публічносmi, демократичності, деідеологізованості, толерантності, системності, ефбективності, інноваційності, гендерної рівності та ін. Зроблено висновок, що набуває актуальності та потребує подальшого впровадження в культурно-мистецьку сберу принцип політичного невтручання в изю сберу та децентралізація державного управління. Аргументовано, шо в Украйні триває процес становлення демократичної держави та громадянсъкого суспільства, сочіальной їх орієнтованості, бормування відповідного нормативно-правового поля культурно-мистецькой сбери суспільних відносин, забезпечен- ня виконання взятих на себе міжнародних зобов'язань, а відтак-входження держави як рівноправної до європейсъкого співтовариства, що досі вимагає концептуального визначення, розробки й реалізаиї державної культурної політики як основи бормування культури та ідентичної украӥнсъкої нациї, адаптаий до світових умов створення культурно-мистецьких изнностей як складової сочіальної демократї.

Ключові слова: культура, мистецтво, державна політика, демократичність, толерантність, деідеологізованість, гендерна рівність.

\section{Актуальність дослідження}

В Україні активно провадиться процес становлення демократичної держави та громадянського суспільства, соціальної їх орієнтованості, формування відповідного нормативно-правового поля культурно-мистецької сфери суспільних відносин, забезпечення виконання взятих на себе міжнародних зобов'язань, що має значно прискорити входження держави як рівноправної до європейського співтовариства. Це вимагає концептуального визначення, розробки й реалізації державної культурної політики як основи формування культури та ідентичної української нації, адаптації до світових умов створення культурно-мистецьких цінностей як складової соціальної демократії.

Мета статті - 3' ясувати сутність, основні принципи та перспективи розвитку дер- 


\section{Цивільне, підприсмницьке, господарське та трудове право}

жавної політики у сфері культури та мистецтва.

\section{Огляд останніх досліджень і публікацій}

Теоретичною базою для підготовки наукової статті послужило компаративне дослідження вітчизняного законодавства про культуру та мистецтво з метою виявлення та аналізу найсуттєвіших характерних рис сучасної державної політики у цій сфері та подальших тенденцій ії розвитку. Оскільки понятійно-категоріальний апарат цієї проблематики характеризується поліваріантністю тлумачення необхідних для формування авторських дефініцій, у цьому дослідженні стало необхідним також звернення до наукових доробок зарубіжних науковців. Так, науково-теоретичним підгрунтям дослідження послужили напрацювання таких провідних вітчизняних і зарубіжних дослідників, як: В. П. Андрущенко, Ю. П. Богуцький, І. Д. Безгін, О. А. Гриценко, С. В. Дрожжина [1], І. М. Дзюба, А. Жерар, С. І. Задворний [2], В. В. Карлова [3], Г. Кремень, В. М. Аитвин, С. I. Малімон [4], А. О. Ручка, О. М. Семашко, В. А. Скуратівський, П. І. Надолішній, І. Ф. Надольний, Б. О. Парахонський, М. В. Попович, Н. С. Фесенко, Р. Фішер, С. А. Чукут та ін. Дослідження сфери культури та мистецтва перебуває в полі зору переважно науковцівкультурологів, мистецтвознавців, політологів, державних управлінців та недостатньо розроблене в юридичній науці, а тому потребує сучасного погляду з поля зору права як основного регулятора суспільних відносин у державі.

\section{Виклад основного матеріалу}

Проблеми, що постали перед суспільством у культурно-мистецькій сфері і про які понад 15 років тому вказувалося у Концепції державної політики в галузі культури, залишаються актуальними й донині. Так, системними прогалинами, що потребували державного втручання та впливу, визнавалися такі, як: а) розрив між так званою офіційною культурою, що фінансується 3 бюджету, і незалежною та орієнтованою на сучасні потреби культурною діяльніс- тю; б) неадекватне вимогам часу фінансове забезпечення галузі культури; в) суттєве погіршення економічної структури видатків місцевих бюджетів на галузь культури; г) розрізнені культурні заходи, які так і не склалися в єдину програму послідовного культурного розвитку [5] тощо.

Основними засадами державної політики у сфері культури є: 1) визнання культури одним з основних факторів самобутності Українського народу - громадян України всіх національностей; 2) сприяння створенню єдиного культурного простору України, збереженню цілісності культури; 3) захист і збереження культурної спадщини як основи національної культури, турбота про розвиток культури; 4) сприяння утвердженню гуманістичних ідей, високих моральних засад у суспільному житті; 5) забезпечення свободи творчості, захист прав інтелектуальної власності, авторського права і суміжних прав; 6) гарантування прав громадян у сфері культури; 7) створення умов для творчого розвитку особистості, підвищення культурного рівня, естетичного виховання громадян, доступності освіти у сфері культури для дітей та юнацтва, задоволення культурних потреб Українського народу, розвитку закладів культури незалежно від форми власності, залучення до сфери культури інвестицій, коштів від надання платних послуг, благодійництва, інших не заборонених законодавством джерел; сприяння діяльності професійних творчих спілок та громадських організацій у сфері культури, активному функціонуванню державної мови в культурному просторі України, доступу громадян до культурних благ; визначення естетичного виховання дітей та юнацтва пріоритетом розвитку культури; 8) забезпечення діяльності базової мережі закладів культури, закладів освіти сфери культури; 9) підтримка діяльності у сфері культури, пов'язаної з виготовленням i розповсюдженням електронних та друкованих засобів масової інформації, аудіо- та аудіовізуальної продукції, розробленням комп'ютерних технологій та підвищенням їх потенціалу для розширення доступу та залучення громадськості до діяльності у 
сфері культури тощо; 10) пропагування української національної культури у всій iii різноманітності за кордоном та світового культурного надбання в Україні; 11) підтримка вітчизняного виробника у сфері культури; забезпечення розвитку міжнародного культурного співробітництва [6] та ін.

У наукових джерелах державна політика у сфері культури визначається як діяльність держави, спрямована на максимально можливе забезпечення основної ролі культури в розвитку і самореалізації сутнісних сил людини, збереження національної самобутності народів, утвердження їх гідності. Основними завданнями державної політики у сфері культури є забезпечення: необхідних організаційно-управлінських, правових, фінансово-економічних умов для створення, збереження та поширення культурних цінностей у суспільстві з метою максимального задоволення культурних запитів різних суспільних груп; прав громадян у сфері культури - свободи творчості, доступу до культурно-мистецьких цінностей; вільного функціонування i розвитку всіх дійсних на території країни національних культур, включаючи і культури національних меншин; спадкоємності культурного розвитку, збереження єдиного культурного простору держави [3, с. 11].

Згідно з ч. 1 ст. 34 Закону України «Про культуру» особи, винні у порушенні законодавства про культуру, несуть дисциплінарну, цивільну, адміністративну та кримінальну відповідальність відповідно до законодавства [6]. Ця правова норма має відсильний характер, що може мати негативні наслідки у сфері захисту порушених прав суб'єктів у сфері культури та мистецтва, оскільки не конкретизує певні види таких правопорушень та відповідні санкції за їх вчинення.

Аналіз законодавства у сфері культури та мистецтва дає підстави стверджувати про приватно-правовий характер відповідних суспільних відносин. Так, приватно-правовий характер правовідносин окремих суб'єктів господарювання у сфеpi, наприклад, театрально-концертної діяльності, 3 іншими учасниками господар- ського обігу проявляється й при укладенні господарських договорів, що забезпечують їх повсякденну діяльність. Це договори відповідних закладів і установ на постачання електроенергії, води, тепла, надання інших комунальних послуг; договори, що регулюють орендні відносини за участю суб'єктів театрально-концертної діяльності; договори про банківське обслуговування фінансових рахунків цих суб'єктів, тощо. При цьому, оскільки предметом цих зобов'язальних відносин виступає не тільки приватне, але і державне та комунальне майно, у т. ч. бюджетні кошти, то правовідносини з приводу укладання та виконання таких договорів набувають публічно-правового забарвлення. Позаяк вказані правовідносини виходять за межі дисертаційного дослідження, детально зупинятися на цьому немає підстав [7, с. 169, 170]. Приватні інтереси суб'єктів досліджуваних правовідносин проявляються й у позадоговірних стосунках. Зокрема, за правилами $§ 2$ гл. 78 ЦК України в організаторів та учасників конкурсів (у сучасному розумінні театрально-концертного бізнесу - шоу-проєктів) виникають зобов'язальні відносини з публічної обіцянки нагороди (премії) за результатами конкурсу. Конкурс характеризується тим, що винагорода оголошується не за виконання певної роботи взагалі, а за найкращий результат, у тому числі внаслідок творчої діяльності. Тобто конкурс зобов’ язує його засновника, який публічно оголосив про нагороду, надати іiі (виплатити) особі, результат якої визнано гідним присудження призового місця відповідно до конкурсних умов.

Якщо спеціальною винагородою у сфері шоу-бізнесу оголошено укладення продюсерського договору, договору про розповсюдження відео- та аудіовізуальних творів тощо, то в такому випадку можна вести мову про наявність переддоговірних відносин, у яких переможець конкурсу за власним волевиявленням або погоджується прийняти винагороду, тобто укласти в подальшому відповідний договір, або відмовляється від цього. При цьому, на нашу думку, не слід ототожнювати подібні переддоговірні правовідносини із зобов'язаннями, що вста- 


\section{Цивільне, підприсмницьке, господарське та трудове право}

новлюються попереднім договором (ч.ч .1 - 3 ст. 635 Цивільного кодексу України).

Позадоговірні відносини у сфері театрально-концертної діяльності виникають також і у зв'язку з діяльністю національних творчих спілок, функціональне призначення яких встановлено Законом України «Про професійних творчих працівників та творчі спілки» від 07.10.1997 р. За цими Міністерства юстиції, в Україні зареєстровано 22 творчі спілки, 3 яких 9 мають безпосередне відношення до театрально-концертної галузі. Приватно-правовий характер таких відносин окреслюється кількома 3 основних завдань, які творчі спілки покликані виконувати у суспільстві в цілому та культурному просторі зокрема. Серед них - розвиток національної культури та мистецтва, розроблення і втілення в життя культурно-мистецьких заходів, організація творчих конкурсів, вечорів, прем'єр, фестивалів тощо; соціальний захист членів спілок; захист авторських прав і творчих свобод професійних творчих працівників; підтримка професійного рівня творчого працівника; створення комунікативного мистецького середовища та ін. 3 цією метою національні творчі спілки наділені як майновими засобами, так і рядом прав по їх використанню, зокрема: здійснювати заходи 3 соціально-економічної підтримки та благодійництва; здійснювати творчу та господарську діяльність у передбаченому законодавством порядку; створювати підприємства, установи, організації, фонди творчих спілок; володіти, користуватися і розпоряджатися майном на правах власника ([8, ст. 3, 9, 23]).

Стратегія державної культурної політики по відношенню до ТКД підлягає цілеспрямованим змінам у напрямку створення чітких правил формування відносин між владою, бізнесом та громадянським суспільством у галузі культури 3 одночасним усуненням держави від ручного управління сферою культури та мистецтва. 3 метою визначення заходів необхідної соціально-економічної підтримки суб'єктів господарювання у галузі культури з боку органів публічної влади та недопущення спотворення чесної економічної конкурен- ції такою підтримкою, недопущення «перехресного субсидіювання» бюджетними коштами комерційної (неосновної) діяльності окремих суб'єктів театрально-концертної діяльності, чинне законодавство України потребує встановлення нормативного критерію щодо розміру покриття витрат на повсякденну діяльність театральних чи концертних організацій за рахунок глядачів та інших дозволених господарських операцій, перевищення якого виключає державну матеріальну підтримку відповідної культурної організації [7, с. 214, 215].

Цікавим видається зарубіжний досвід публічно-правового регулювання мистецької сфери. Так, одними 3 найбільш ефективних вважаються американська та британська моделі державної політики у сфері культури (США, Фінляндія, Велика Британія), які є найбільш ринковими та реалізують принцип політичного невтручання держави у питання фінансування таких сфер і функціонують за рахунок приватних інституцій, (Національна рада у сфері мистецтва, Великобританія) [9]. Що стосується ситуації в нашій країни, більшість дослідників сходяться на думці, що сучасна сфера культури та мистецтва України перебуває на стадії модернізації та потребує подальшої децентралізації та невтручання політичних сил, а також застосування консультативно-дорадчих послуг з боку держави i залучення іноземних та приватних інвестицій у цю царину [10, с. 10].

Державне регулювання у сфері культури та мистецтва здійснює Міністерство культури України (Мінкультури), яке є центральним органом виконавчої влади, діяльність якого спрямовується і координується Кабінетом Міністрів України. Мінкультури є головним органом у системі центральних органів виконавчої влади, що забезпечує формування та реалізує державну політику у сферах культури та мистецтв, охорони культурної спадщини, вивезення, ввезення і повернення культурних цінностей, державної мовної політики, а також забезпечує формування та реалізацію державної політики у сфері кінематографії, відновлення та збереження національної пам'яті. Це міністерство виступає спеціально уповно- 
важеним центральним органом виконавчої влади у сфері міжнаціональних відносин, релігії та захисту прав національних меншин і діє відповідно до Положення [11], затвердженого постановою Кабінету Міністрів України від Звересня 2014 р. № 495.

\section{Висновки}

Відносини у сфері культури та мистецтва мають господарську приватно-правову природу. Основні засади державної політики у цій сфері в Україні врегулювано на законодавчому рівні, що слід, безперечно, вважати позитивним фактором для подальшої адаптації законодавства України до законодавства EC. На сьогодні основними принципами, на яких грунтується державна політика у сфері культури та мистецтва, є принципи: прозорості і публічності, демократичності, деідеологізованості, толерантності, системності, ефективності, інноваційності, гендерної рівності та ін. На сьогодні набуває актуальності та потребує подальшого впровадження в культурномистецьку сферу принцип політичного невтручання в цю сферу та децентралізація державного управління. Відтак у майбутньому набуватиме свого поширення корпоративне нормотворення, завдяки чому стане найбільш ефективним та своєчасним врегулювання особливостей окремих напрямів діяльності у сфері культури та мистецтва. Потребує свого удосконалення i практика нормотворення у сфері юридичної відповідальності за правопорушення у сфері культури та мистецтва, зокрема, їх диференціації та визначення юрисдикційних та позаюрисдикційних форм захисту прав суб'єктів культурно-мистецьких відносин, що, безперечно, сприятиме захисту прав та основоположних свобод людини та громадянина.

\section{Мiтература}

1. Дрожжина С. В. Культурна політика як проблема сучасного соціокультурного процесу : автореф. дис. ... філос. наук : 09.00.03; Донец. нац. ун-т. Донецьк, 2004. $17 \mathrm{c}$.

2. Задворний C. I. Територіальна організація культурно-мистецької сфери регіо- ну (на матеріалах Хмельницької області): автореф. дис. ... канд. геогр. наук: 11.00.02; Аьвів. нац. ун-т ім. І Франка. Аьвів, 2016. $21 \mathrm{c}$.

3. Карлова В. В. Державна політика у сфері культури: сутність та особливості реалізації в сучасних умовах : автореф. дис. ... канд. наук держ. упр. : спец. 25.00.01; Укр. акад. держ. упр. при Президентові України. Київ, 2003. 18 с.

4. Малімон В. І. Культурна політика держави як чинник реформування суспільства : автореф. дис. ... канд. наук з держ. упр. : 25.00.02; Івано-Франків. нац. техн. ун-т нафти і газу. Івано-Франківськ, 2011. 20 с.

5. Про Концепцію державної політики в галузі культури на 2005 - 2007 роки: Закон України від 14 груд. 2010 р. № 2778VI. Оббічійний вісник України. 2005. № 13. Ciт. 660.

6. Про культуру: Закон України від3 берез. 2005 р. № 2460-IV. Оøіиійний вісник Украйни. 2011. № 12. Ст. 91.

7. Костюкова А. О. Господарсько-правове регулювання театрально-концертної діяльності: дис. на здоб наук. ступ. канд. юрид. наук: 12.00.04; Навчально-науковий Інститут права імені князя Володимира Великого ПрАТ «Вищий навчальний заклад «Міжрегіональна Академія управління персоналом», Національний університет «Одеська юридична академія». Одеса, 2020. $251 \mathrm{c}$.

8. Про професійних творчих працівників та творчі спілки: Закон України від 07.10.1997 р. №554/97-ВР. Відомості Верховноӥ Ради Украӥни. 1997. № 52. Ст. 312.

9. Ігнатченко I. В. Особливості реалізації державної політики України у сфері культури: сучасний стан та світові стандарти. Теорія та практика правознавства. 2013. Вип. 1. URL: https://dspace.nlu.edu. ua/bitstream/123456789/ 3698/1/Ignatch.pdf (дата звернення: 01.08.2021).

10. Мерзляк А. В. Державне управління сферою культури: вітчизняний та зарубіжний досвід. Публічне адміністрування: теорія та практика. 2017. Вип. 1 (17). С. 1-13.

11. Про затвердження Положення про Міністерство культури України пост. Кабінету Міністрів України від 3 вересня 


\section{Цивільне, підприсмницьке, господарське та трудове право}

2014 р. № 495. Офіційний вісник України. 2014. № 81. Ст. 2285.

LEGAL BASIS OF THE STATE POLICY IN THE SPHERE OF CULTURE AND ART

The article is devoted to the research of essence and peculiarities of social relations in the sphere of culture and art and elucidation of tendencies of further state influence on the cultural sphere. The methodology of research in the sphere of culture and art is based on the general scientific dialectical method. At the same time, the formal-legal and formal-logical methods were used for a more detailed and detailed disclosure of the topic of the scientific article. It is proved that relations in the sphere of culture and art have an economic privatelegal nature. The basic principles of state policy in this sphere in Ukraine are regulated by law, which should be undoubtedly considered as a positive factor for the further adaptation of Ukrainian legislation to the EU legislation. It has been proved that today the basic principles, on which the state policy in the sphere of culture and art is based, are the principle of transparency and publicity, democracy, de-ideologization, tolerance, consistency, effectiveness, innovation, gender equality, etc. It is concluded that the principle of political non-interference in this sphere, as well as the principle of decentralization of the state administration, has become urgent and requires further introduction in culture and art. It has been argued that Ukraine is in the process of establishing a democratic state and civil society, their social orientation, the formation of the regulatory field of cultural and artistic sphere of social relations, ensuring compliance with international obligations, and then enter the state as an equal member of the European community, still requires a conceptual definition, development and implementation of state cultural policy as the basis for the formation of culture and identity

Keywords: culture, art, state policy, democracy, tolerance, de-ideologization, gender equality. 